\title{
Developing Teaching Material Charged with Quran Values to Improve Metacognitive Knowledge
}

\author{
Fatma Masitah ${ }^{1, *}$ Dadan Rosana ${ }^{2}$ \\ ${ }^{1,2}$ Universitas Negeri Yogyakarta, Indonesia \\ *Corresponding author. Email: fatmanurilmasitah@gmail.com
}

\begin{abstract}
This research aims to: (1) develop a teaching material charged with Quran values to improve metacognitive knowledge for high school students. (2) knowing the effectiveness of the developed teaching materials. This research used research and development methodology that using the 4D model, namely (1) defining learning needs; (2) designing product draft; (3) developing product assessed by experts and practitioners, product trials, and product revisions; (4) disseminating the final product. The developed teaching material contained the wave material with the Alquran value. The limited trial subjects were 10 learners. The subjects in the experimental class were 20 people and in the control class 21 people. The data collection instruments used include a teaching material assessment sheet, an assessment sheet of the knowledge ability, and a student response poll of the teaching materials. The data analysis technique utilized the assumption test phase, N-gain, Hotelling's multivariate statistical test and the effect size analysis. This research resulted in (1) a learning material charged with the Al Quran value that has fulfilled the eligibility criteria, based on the assessment by expert lecturers and practitioners. (2) The developed teaching materials get good responses from learners. (3) The developed teaching materials are effective in improving metacognitive knowledge skills.
\end{abstract}

Keywords: metacognitive knowledge skills, teaching materials, research and development.

\section{INTRODUCTION}

The 21 st century is the era of globalization or the open era that gave rise to many fundamental changes compared to the previous century. Changes that occur according to Fadel and Triling [1], among others, in the field of technology, transportation, economics, resource management, as well as changes in the trend of jobbased industry that used to be knowledge-based. The changes certainly have an effect on the culture and education so that required a thought which can produce good quality output [2] to the current society can live and work in a time of knowledge especially for field Education [3]. Article 1 Act No. 20 Year 2003 of the national education system mention that sense education is planned and conscious effort to bring about an atmosphere of learning and the learning process so that learners actively develop the potential for him to have a religious spiritual strength, self-control, personality, intelligence, morals, as well as the necessary skills themselves, the community, the nation and the State. So in the process of education, at least there should be teachers, students, educational purposes, materials, media education, and evaluation [4].

In Indonesia, the evaluation is governed by Permendikbud No. 542013 in regard to the competency standards of graduates. It is explained about the criteria that learners need to achieve, such as knowledge, attitudes, and skills. The evaluation of student's learning outcomes requires some aspects to be done, among others, for mechanisms, learning assessment instruments and procedures. Evaluation of learner's learning results is the effort to collect and process the data obtained through learner's learning outcomes to measure the level of achievement of graduation criteria. The assessment for Student's learning outcomes has various types, such as written assessments, self-assessments, replay, and so on. To determine student's knowledge competence, we use written assessment.

Students' knowledge can be achieved by doing remembering activities, understanding, implementing applications, conducting analysis, working on evaluations, and bringing new things up. Knowledge according to Permendikbud No. 21 of 2016 is grouped 
into procedural, factual, conceptual, and metacognitive knowledge.Metacognitive knowledge is the key to successful learning competencies in various fields, including education [5] - [8]. Metacognitive knowledge is a knowledge of a person's cognition activity in the learning process [9]. Metaconitive knowledge may change at any time according to the person's condition who learn metaconitive knowledge [10]. Thus, metacognitive knowledge can be used to control cognitive skills [11], [12] and problem solving skills [13] so that learners can learn better [14]. Metacognitive skills will bring up planning, monitoring, and evaluation skills. Research conducted by Kusuma \& Nisa [15] explained that metacognitive skills contributed $81.08 \%$ to cognitive learning outcomes.

Based on the description, which can be done to support the achievement of knowledge learners aspects, namely the need for the creation of teaching materials [16] containing with Alquran values.

The Ministry of National Education in 2008 explained that the existence of teaching materials is considered important because it relates to the demands of the curriculum on the teaching material's availability, target characteristics, and learning problems. Soegiranto [17], said that the materials and materials used in the learning process systematically arranged for learners are called teaching materials. The development teaching materials by teacher shows a positive impact on learner's learning activities [18] and makes learning more effective [19], [20]. According to Prastowo [21] teaching materials also have the advantage that it can be used as a reference in carrying out the teaching and learning process in class and become a reference teacher or instructor. Teaching materials must meet visual elements such as display balance, colour selection, readability, and attractiveness of teaching materials. In addition to these elements, teaching materials must certainly pay attention to the text and the way it is written.

While according to Widodo \&Jasmadi [22], the teaching materials need to observe the following elements, learning materials should be adapted to the conditions of the learner while carrying out the learning process, learning materials are expected to be able to change the behaviour of learners, the development of learning materials tailored to the needs and characteristics of the self, learning materials include objectives specific learning activities, learning materials contains a good learning material in the form of activity or exercise with detailed, learning materials include part of evaluation as a tool to measure the success of the learning learners [22].

Teaching materials are an important factor supporting the teaching and learning activities implementation. That is maximized if the use of teaching materials is adjusted to the students conditions.
That way, the material can be delivered to be more easily absorbed by the learners. A school that has required the participants to study the Quran to understand the interpretation contained in the Quran can use the teaching materials. So that students can make the Quran as a foundation in learning and understanding the wave material at once can add spiritual value. A narrated by Imam Nasai and Muslim.

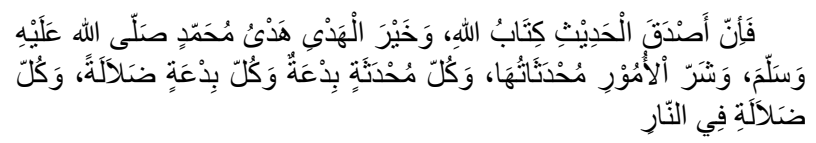

Indeed, the most correct words are the kitabullah, the good instruction is the instruction of the Prophet Muhammad, a bad thing is a new thing, every new thing heretic, every matter of heresy is misleading, and everything misleading will lead us to Hell (HR Imam Nasai and Muslim)

explaining that the best teaching material is Quran. Learners are able to digest the material by wave analysis of events that exist because the search of knowledge through sight, hearing, and contemplation. Then the students are expected to develop metacognitive knowledge, without leave spiritual attitude.

Research on the use of printed materials has been conducted by French, Taverna, Neumann, Kushnir, Harlow, Harrison, and Serbanescu [23]. They observed more than a thousand students on 12 undergraduate programs from the university in a large urban center and a university in a small urban center that uses textbooks. A total of 77 percent of students admitted often using textbooks and 25 percent of students read only textbooks at any given moment. As a result, those who often read textbooks have a better value at the end of the lecture. Heliawati and friends research [24] also explained that use modules that are integrated with religious values is effectively used. Teaching materials are also important to help improve learning process quality and can reduce the potential for misconceptions that can arise in learning [25]. FurthermoreGurat and Medula [26] conducted research on several schools in the Philippines. They were interviewed to complete the initial data. Then the collected data is analyzed, then it is known that metacognitive knowledge has 3 stages, namely preparation, production, and evaluation. The result of metacognition can be used as an indicator of success in the study of instructional thinking patterns. Dini Maielfi [27] has also developed a physics learning device with the CTL-based approach of faith and Taqwa aimed at the students of the MAN 2 Padang. His learning devices have been validated and are wellreceived by practitioners, experts, and learners. Thus, teaching materials containing Aquran value are considered important for use by learners Method.

This study explores the development teaching materials containing Alquran value and the 
effectiveness teaching materials. This development uses research and development model including validation by physics lecturers and physics teachers after carrying out development [28]. Hopefully, with the research output production in the form teaching materials can improve the metacognitive ability learners.

\section{RESEARCH METHOD}

This research used research and development methodology that used to get defined and verified product quantitatively. The developed products was teaching materials with the Quran values to improve students knowledge competence at high school subject waves. As for the development of the following procedure:

\subsection{Define stage (Definition).}

Stage define aimed to established and defined the needs in the learning process. The definition stage had 5 main steps, including

\subsubsection{Initial analysis}

Initial analysis aimed at establishing the fundamental problems that arised when Physics learning process in high school included curriculum problems as well as other problems so that teaching materials development was needed.

\subsubsection{Student analysis}

Student analysis aimed to know the students characteristics which included development level students metacognitive knowledge.

\subsubsection{Task analysis}

Task analysis aimed to carry out analysis in determining learning unit content that reviewed basic competencies and core competencies in accordance with the 2013 curriculum. The subject that will be developed in teaching materials was a special wave material at the high school level charged with Quran values.

\subsubsection{Concept analysis}

Concept analysis aimed to identify the main concepts will be taught. Furthermore, systematically and detailing relevant concepts and linking concepts with other concepts so that concept maps were formed.

\subsubsection{Specification learning objectives}

Specification learning objectives was intended to formulate learning objectives based on Core Competencies and Basic Competencies contained in the curriculum on a material concept.

\subsection{Design stage (Design)}

The purpose this stage was to prepare a prototype learning materials. At the design stage, there were 3 steps that must be done, namely: media selection, format selection, initial design physics teaching materials for wave material charged with Alquran values.

\subsection{Develope Stage (Development)}

This stage aimed to produce learning materials with Alquran values revised based on comments, suggestions, and the assessment of expert lecturers, physics teacher, field test, and the operational field test. Teaching material wave materials charged with Alquran values, observation sheets and pretest and posttest questions the results of the design stage must passed the validation stage to improve the initial design. Expert lecturers validation was done by UNY graduate lecturers. Validation technique was by filling out the revised questionnaire. Then the validation was carried out by 2 high school physics teachers.

\subsection{Deseminate stage (desemination).}

This stage aimed to use teaching material that has been developed on a wider scale that is in 2 classes (limited test classes and operational field test classes).

\section{DATA ANALYSIS TECHNIQUES}

The data processing using qualitative descriptive analysis technique, which was the technique to describe and used qualitative data. Qualitative Data obtained from material experts, media experts, physics teachers, peers, and learners was expertly quantized, for later analysis. But the analysis of the interviews and documentation was still using qualitative analysis.

\subsection{Quisioner instrument}

On quisioner instrument, we got qualitative data. Because it, we must did calculations first, so that it could be presented quantitatively.

\subsection{Test instrument}

Before and after the treatment each group This test data could be given. In this study, we got student's metacognitive knowledge data. The form of test used in the initial test and also the final test in this study was a reasoned multiple choice question.

The improvement of students' ability on the subject matter of waves was measured by calculating the gain of the value of learners before and after physics learning activities. 


\subsection{Analysis student's metacognitive knowledge to each group}

Effectiveness analysis of teaching materials was used to determine teaching materials effectiveness by reviewing the student's metacognitive knowledge abilities in each group. At this stage it required data difference between the initial test results and the final test for students called data gain.

\section{RESULT AND DISCUSSION}

The initial product development resulted in a rough draft teaching material of vave material charged with Quran values that has been assessed by experts and practitioners. The data descriptions preliminary product development are explained in the following stages of development.

\subsection{Define stage (definition) result}

First, initial analysis aims to set a fundamental issue that emerged in the curriculum and field problem in the physics learning for high school so that the teaching materials needed development. At this stage, observations and interviews. Through interviewing activities, it is known that the teaching materials are used to customize the direct instruction. The materials contain a material summary and questions. The concept teaching material is too short that requires additional explanation on other teaching materials that support the learning process. Physics teacher has difficulty in explaining abstract materials such as waves. Learners are less able to imagine events about waves in everyday life. The results of literature study present an alternate way as a solution to existing problems when learning in class. The alternative way of providing other teaching materials as a supporter teaching materials that have been used is the teaching materials that are charged the Quran value. Learners are expected to improve metacognitive knowledge accompanied by increased spiritual attitude.

\subsection{Design stage (design) result}

The results at the design stage teaching materials prototype. Selection media is tailored to easy delivery basic materials so that learning objectives can be achieved. For the development materials teaching using Microsoft Word. Designing the teaching materials format in accordance with the analysis results of theory and analysis in the define stage. Based on the format design, it can be designed early teaching materials. The learner's ability Format is about the description to assess metacognitive knowledge. The Student ability Assessment sheet is given during posttest and pretest. The initial draft of the teaching materials and data collection instruments are further submitted to the guiding lecturers to be consulted. The guidance lecturers then provide correction and input to the teaching materials for further assessed by expert lecturers and practitioners.

\subsection{Development stage (development) result}

The validation process when data collection instruments aims to allow the instrument to measure the results of the actual research. The result of such validation is

Table 1. Result of such validation

\begin{tabular}{|l|l|l|l|l|}
\hline No & Instrument & $\begin{array}{l}\text { Validity } \\
\text { Coef. }\end{array}$ & Interpretation & Reliability \\
\hline 1 & $\begin{array}{l}\text { Teaching materials } \\
\text { assessment sheet }\end{array}$ & 1,00 & Valid & Reliable \\
\hline 2 & $\begin{array}{l}\text { Student response } \\
\text { questionnaire }\end{array}$ & 1,00 & Valid & Reliable \\
\hline
\end{tabular}

Based on the results of input from FGD and expert lecturers, it can be revised against data collection instruments. Further revision results are consulted to the guidance lecturer. The process of content or items assessment instrument's validation of metacognitive knowledge assessment is carried out by three expert lecturers and two physics teachers. The validity aspect is comprised material, construction, and language aspects. Instrument content validity of metacognitive knowledge assessment is calculated using validity coefficient. All of 12 item show validity coefficient 1,00 and the interpretation is valid.

At the development stage, there were wave materials that received improved assessment, suggestions and based on comments by expert lecturers and practitioners. Observation on material content of the materials is based on the concept of appropriate theory, while the use of procedures of writing materials adapted to Permendikbud number 50 year 2015 using simple language and easy to understand. Next 2 expert lecturers and 2 teachers validate the teaching materials. Result data obtained is the data in the form scoring scores and data in the category teaching materials score.

Table 2. result data obtained in the teaching materials score category

\begin{tabular}{|l|l|l|l|}
\hline No & Aspects & Average score & Category \\
\hline 1 & Content & 3,83 & Very good \\
\hline 2 & Material layout & 3,58 & Very good \\
\hline 3 & Linguistic & 3,58 & Very good \\
\hline 4 & Graphics & 3,83 & Very good \\
\hline \multicolumn{2}{|l|}{ Average } & 3,70 & Very good \\
\hline
\end{tabular}

Comments and suggestions about the teaching materials are further provided by the expert lecturers and the further physics teachers are consulted with the Supervisor lecturer to get the input as revised material described in the product revision. After that, comments and suggestions by the physics teacher and expert lecturers have been revised, then will be generated teaching materials that are subsequently used in the limited trial. Limited trials are conducted to search 
response data, comments and suggestions from developed materials users. Afterwards the teaching materials were given to 10 students of the XI SMA class for testing. Developed teaching materials got $10 \%$ response with excellent categories, $70 \%$ with good categories, and $20 \%$ with enough categories. Total score value from all statements on a poll has a less value than 0.05 and Cronbach's Alpha overall value is 0.844 (greater than 0.600). These results correspond to the hypothesis that the SPSS testing is a rejection of $\mathrm{H} 0$ which means the data shows valid and reliable (consistent) results. The responses or suggestions provided by students to the teaching materials are consulted with the guidance lecturers to get improvement of the teaching materials that will be tested in the field. The validity and reliability knowledge assessment sheet and spiritual attitude assessment is conducted by 10 students of XI SMA class. The assessment results are further analyzed using SPSS program. According to the empirical validity instrument's result the metacognitive knowledge assessment, all items can be said to be valid and reliable. The basic data is said to be valid is to have a total score of less than 0.05 so that the decision obtained rejection of $\mathrm{HO}$ (according to hypotheses that lubricated SPSS). While the results of the assessment instrument is said to be reliable because it has a value of Cronbach's Alpha more than 0.600 which is 0.745 so that the decision obtained rejection $\mathrm{H} 0$ which means all the matter of reliability or consistent. A revised teaching and learner's ability to input and comment on the next limited trial in a different class is again tested as a field trial. On the field trials, the teaching materials received a student response of $45 \%$ with excellent categories and $55 \%$ with good categories. The experimental classes and the control class were used as field trials for Posttest and pretest execution. The final results of the pretests and posttest in the experiment class and the control class are presented in the table below.

Table 3. final results of the pretests and posttest in the experiment class and the control class

\begin{tabular}{|l|l|l|l|l|}
\hline \multirow{2}{*}{ No } & \multirow{2}{*}{ Class } & \multicolumn{3}{|c|}{ Average value of metacognitive knowledge } \\
\cline { 3 - 5 } & & Pretest & Posttest & $N$-gain \\
\hline 1 & experiment & 40,6 & 85,65 & 0,78 \\
\hline 2 & control & 40,76 & 76,05 & 0,59 \\
\hline
\end{tabular}

The table shows the results of changing learners ability to be read through $\mathrm{N}$-gain interpretation. In experimental classes, metacognitive knowledge n-Gain is 0.78 which is classified in high category. While in the control class, metacognitive knowledge N-Gain is 0.59 which is a medium category.

Effectiveness testing to use teaching materials on metacognitive knowledge ability enhancement is carried out using multivariate statistical tests because it has more than one dependent variables [29]. A multivariate test can be performed after a test of assumptions, which should be done first is the assumption of the population variables that are both normal and homogeneous distributions [30]. The data used is increased capability or gain data.

After knowing there is a difference in the increasing metacognitive knowledge, it can be seen how much the influence of teaching materials to the metacognitive knowledge by using effect size. Effect Size is a measure magnitude of the variables effect in other variables, the magnitude of difference and the free relationship of the sample magnitude influence. Here are the calculation results in brief.

Table 4. Calculation results

\begin{tabular}{|l|l|l|l|l|}
\hline No & Variable & $\begin{array}{l}\text { Eta } \\
\text { Squared }\end{array}$ & Cohen's $f$ & Interpretation \\
\hline 1 & $\begin{array}{l}\text { Metacognitive } \\
\text { knowledge }\end{array}$ & 0,372 & 0,40 & high effect size \\
\hline
\end{tabular}

Based on the analysis, Cohen's f value with high effect size interpretation on metacognitive variable. The results showed that the teaching materials charged Alquran values has a major influence on the enhancement metacognitive knowledge. Therefore, it can be concluded that the using teaching materials with the Alquran values is effective to increase learner's metacognitive knowledge.

\subsection{Dissemination stage result (Dissemination)}

The final product that has been through the revision stage and subsequent assessment can be carried out to the school that has been using the 2013 curriculum based on Alquran education. Limited distribution to certain schools because the worry of understanding students who do not get the Quran education will have difficulty understanding materials materials. The teaching materials are given to the class teachers of XI SMA Ali Maksum and MA Almahali teacher by providing explanations on how to use. Advice given by the physics teacher is expected to be charged teaching materials the Quran value is able to be used by all high school.

\section{CONCLUSION}

This research results materials that have fulfilled the eligibility criteria. The eligibility criteria of the teaching materials are based on assessment by expert lecturers and practitioners. The application of teaching materials is effective to improve the ability of metacognitive knowledge. The effectiveness teaching materials is reviewed based on the implementation of field trials.

Teaching materials are used by students who have studied the Quran in depth. The author hope that teaching materials with Alquran values can be used by all students with diverse backgrounds. 


\section{REFERENCES}

[1] Trilling, B danFadel, C. (2009) 21st Century Skills Learning For Life In Our Times. USA: HB Printing.

[2] Tilaar. (1998). ParadigmaBaruPendidikanNasional. Jakarta: RinekaCipta

[3] Trilling, Bernie dan Hood, Paul. (1999). Learning, Technology, and Education Reform in the Knowledge Age, (Online), (https://www.wested.org/online_pubs/learning_tec hnology.pdf)

[4] Twyman, Janet S danHeward, William L. (2016). How to Improve Student Learning in Every Classroom Now. International Journal of Educational Research, 1149, 13. (http://dx.doi.org/10.1016/j.ijer.2016.05.007)

[5] Efklides, A. (2014). How Does Metacognition Contribute to the Regulation of Learning? An Integrative Approach. Psychological Topics, 23, 130

[6] Gomes, C. M. A., Golino, H. F., \& Menezes, I. G. (2014). Predicting School Achievement Rather than Intelligence: Does Metacognition Matter? Psychology, 5, 1095-1110. (https://doi.org/10.4236/psych.2014.59122)

[7] Panadero, E. (2017). A Review of Self-Regulated Learning: Six Models and Four Directions for Research. Frontiers in Psychology, 8, 422. (https://doi.org/10.3389/fpsyg.2017.00422)

[8] Veenman, M. V. J. (2016). Metacognition. In P. Afflerbach (Ed.), Handbook of Individual Differences in Reading: Reader, Text, and Context (pp. 26-40). London: Routledge

[9] Vrieling, E. M., Bastiaens, T.J., \&Stijnen, S. (2012). Effects of increased self-regulated learning opportunities on student teachers' metacognitive and motivational development.International Journal of Educational Research, 53 (2012), 251-263, (http://dx.doi.org/10.1016/j.ijer.2012.03.014)

[10] Crescenzi, Anita. (2016). Impacts of Time Constraints and System Delays on User Experience. DOI: $10.1145 / 2854946.2854976$

[11] Veenman, M. V. J. (2012). Metacognition in science education: Trends in current research. In A. Zohar \& Y. J. Dori (Eds.), Metacognition in science education: Definitions, constituents, and their intricate relation with cognition (Vol. 40). Springer Netherlands. (https://doi.org/10.1007/97894-007-2132-6)
[12] Veenman, et al. (2014). The Online Assessment of Metacognitive Skills In A Computerized Learning Environment, Learning and Individual Differences, $29,123-130$.

[13] Tachie, S. A. (2019). Metacognitive skills and strategies application: How this helps learners in mathematics problem-solving. Eurasia Journal of Mathematics, Science and Technology Education, 15(5), 1-2

[14] Hrbáčková, K., Hladík, J., \& Vávrová, S. (2012). The relationship between locus of control, metacognition, and academic success. Procedia Social and Behavioral Sciences, 69, 1805-1811. (https://doi.org/10.1016/j.sbspro.2012.12.130)

[15] Kusuma, Anindita dan Nisa, Khairun. (2018). Hubungan Keterampilan Metakognitif Dengan Hasil Belajar Mahasiswa S1 PGSD Universitas Mataram Pada Pembelajaran Menggunakan Pendekatan Konstruktivisme. Jurnal Ilmiah Profesi Pendidikan, vol 3 no 2, p. 140-145.

[16] Dewitt, D., Siraj, S., \& Alias, N. (2014). Collaborative Learning : a Module for Learning Secondary School Science. Educational Technology \& Society, 17 (1), 89-101

[17] Soegiranto,M.A.(2010). Acuan Penulisan Bahan Ajar Dalam Bentuk Modul. Pokja Kurikulum dan Supervisi Pusat Pengembangan Madrasah Kementrian Agama Provinsi Nusa Tenggara Timur

[18] Aina, K.J. (2013). Instructional Materials and Improvisation in Physics Class: Implications for Teaching and Learning. IOSR Journal of Research \& Method in Education (IOSR-JRME) eISSN:2320-7388, p-ISSN:2320-737X vol 2, issue 5 , pp 38-42

[19] Oladejo, M.A. (2011). Instructional Materials and Students' Academic Achievment in Physics: some policy implications. European Journal of Humanities and Social Sciences vol 2 no 1

[20] Sejpal, Kandarp. (2013). Modular Method of Teaching. International Journal for Research in Education vol 2 issue 2. (IJRE) ISSN:232009091X

[21] Prastowo, A. (2012). Panduan Kreatif Membuat Bahan Ajar Inovatif. Yogyakarta: Diva Press

[22] Widodo, Chomsin S dan Jasmadi.(2008). Panduan Menyusun Bahan Ajar Berbasis Kompetensi. Jakarta: PT Elex Media Komputindo

[23] French, Michelle.,Taverna, Franco., Neumann Melody., Kushnir, Lena Paulo., Harlow, Jason., Harrison, David., \&SerbanescuRuxandra. (2015). 
Textbook Use in the Sciences and Its Relation to Course Performance. http://www.tandfonline.com/loi/vcol20, 63 (4), 171-177, http://dx.doi.org/10.1080/87567555.2015.1057099

[24] Heliawati, Leny., Permana, Irvan., dan Kurniasih, Elvi. (2020). Student Communication Skills from Internalizing Religious Values to Energy Modules in Life Systems. Jurnal Inovasi Pendidikan IPA, 6(1), 2020, 126-134. (https://doi.org/10.21831/jipi.v6i1.32307)

[25] Nurhadiyanto, D.,Wagiran, \&Mujiyono. (2004). Laporan Penelitian: Reduksi Miskonsepsi dalam Perkuliahan Fisika melalui penerapan Modul dengan Model Pembelajaran Berorientasi Konstruktivistik. Yogyakarta: UNY

[26] Gurat, Melanie G danMedula, Cesar T. (2016). Metacognitive Strategy Knowledge Use through Mathematical Problem Solving amongst Preservice Teachers. American Journal of Educational Research, 4 (2), 170-189, doi: https://10.12691/education-4-2-5
[27] Maielfi, Dini., Ratnawulan., dan Usmeldi. (2012). Pengembangan Perangkat Pembelajaran Fisika dengan Pendekatan Contextual Teaching Learning Berbasis Iman dan Taqwa. Jurnal Penelitian Pembelajaran Fisika I (2012) 1-14, (doi.org/10.24036/jppf.v1i1.602)

[28] Santyadiputra, Gede Saindra; Pradnyana, I Made Ardwi. (2017). Validasi Bahan Ajar Berbasis Model Project-Based Learning pada Matakuliah Sistem Informasi. Seminar Nasional Riset Inovatif. ISBN : 978-602-6428-11-0.

[29] Sutrisno, S., Wulandari, D. (2018). Multivariate Analysis of Variance (MANOVA) untuk Memperkaya Hasil Penelitian Pendidikan. Vol. 9 no.1. https://doi.org/10.26877/aks.v9i1.2472

[30] Stevens, J. P. (2009). Applied Multivariate Statistics for The Sosial Sciences Fifth Edition. New York: Taylor \& Francis group. 